INDONESIAN JOURNAL OF ECONOMICS, SOCIAL, AND HUMANITIES

ijesh.unri.ac.id

\title{
The influence of Corporate Governance Mechanism Towards Company Performance
}

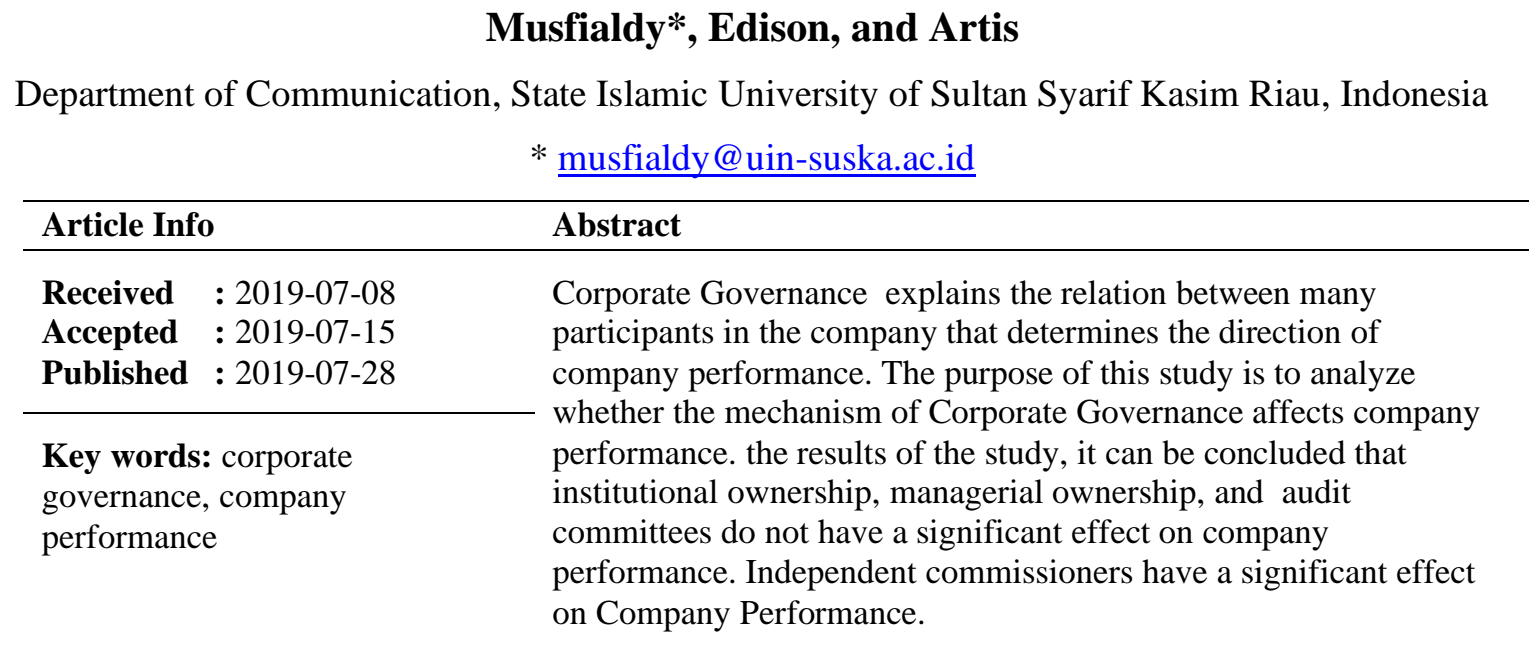

\section{Introduction}

One of the purpose of the company is to increase the welfare of owner through the improvement of a company. High company value can be achieved if the company is able to operate optimally. The existence of profit growth then the company has a high performance. High profits, the company is able to provide dividends to shareholders, high company growth will maintain the company viability. Corporate Governance is corporate governance that determines the direction of company performance. Through the implementation of Good Corporate Governance (GCG), the company is expected to be able to improve performance through the creation of a better decision making process, improve the operational efficiency of the company, and able to improve the services to stockholders. With high performance, companies can more easily obtain financing so as to increase corporate value. High performance, the company is able to increase investor confidence in investing.

Issue about Corporate Governance is began when Indonesia in 1998 started to experience a prolonged crisis. One of the causes of the long process of improvement in Indonesia is because the weak implementation of Corporate Governance which is applied to companies in Indonesia. In 2008 and 2009 the world economic crisis occurred. In 2007, the world economic growth is decreased from 4,9\% into 3,7\%. In 2008, economic growth is occurred amounted 3,8\%. Indonesia really need assistance from foreign shares. At the time of the crisis, foreign investor withdrew their investment. This situation resulted in a fall in the value of the Indonesian currency. The government bears all financing for economic development, especially bank loans and private company debt.

From the phenomenon above, the implementation of Corporate Governance can improve management effectiveness in decision taking. The company manager creates good, efficient and favorable conditions for the company performance. Submission of non-transparent information is an obstacle for company in implementing GCG. The application of good GCG principles, form investor confidence and encourage the entry of new investments to create effective internal incentives for company management. GCG creates the efficient use of resources so that it has an impact on the economy from the macro side as well as the micro side. The sustainability of the 
company can be maintained in implementing appropriate strategies to improve the company performance. Maintaining the company performance that has been achieved. Company performance needs to be done to assess or measure results. Performance appraisal and measurement helps management in the decision making process. This performance shows to investors and other interested parties that the company has good credibility.

Bathala et al. (1994) conclude that strong institutional ownership will reduce the company agency problem. Institutional ownership consists of share ownership by the government, financial institutions, legal entity institutions, foreign institutions, trust funds and other institutions at the end of the year (Cornelius, 2007), which states that institutional ownership can decrease agency costs. Institutional oversight can lead to reduced debt. Debt is a monitoring tool for institutional ownership. Institutional ownership can reduce agency cost of debt. Managerial ownership is share ownership by company management (Sujono and Soebiantoro, 2007). Bathala et al. 1994) stated that managerial stock ownership is number of common shares owned by management. The proportion of managerial ownership in a company shows that there is a common interest between management and shareholders. Increase the proportion of shares owned by managers and directors will reduce excessive manipulation, so as to unite the interests of managers and shareholders. According to (Faisal, 2005), the proportion of the total managerial shareholding of a company shows that there is a congruence of interests between management and shareholders. Improved performance is the desire of shareholders.

In the context of implementing good corporate governance, the Indonesia Stock Exchange (IDX) published a regulation of July 1, 2001, which regulates the establishment of an independent commissioner and audit committee. (Gunarsih, 2003) states that the duties of the board committee is to ensure the implementation of the company strategy, supervise management in managing the company and requiring the company accountability to be conducted. The existence of audit committee is form of effort to improve manner in managing the company, especially how to supervise the company management. Because the audit committee becomes the link between the company management and the board of commissioners and other external parties (Darwis, 2009) states that companies that report higher profits than they should have are that the company does not have an audit committee .

This research aims to find out the relationship of Corporate Governance which is implemented in company with company performance.

\section{Theoretical Framework and Hypothesis Development}

According to (Sulistiyani and Rosidah, 2003), People performance is a combination of ability, effort, and opportunity that can be assessed from their work (Hasibuan, 2012), states that performance appraisal is a formal procedure conducted in an organization to evaluate employees and their contributions and interests for employees. (Shien, et.al, 2006), stated that Institutional ownership is the shares ownership by the government, financial institution, legal entities, foreign institution, trust funds and other institution at the end of the year. According to (Kartikawati, 2007), institutional ownership is one of the factors that can affect company performance. The existence of ownership by institutional investors will encourage increased oversight that is more optimal for management performance, because shares ownership represents a source of power that can be used to support or vice versa on management performance. (Anindhita, 2010) states that the strict supervision conducted by institutional investors is very dependent on the amount of investment made. (Bathala et al., 1994) also found that institutional ownership replaced managerial ownership in controlling agency costs. The greater ownership by financial institutions, the greater the strength of the voice and encouragement of financial institutions to oversee 
management and consequently will provide greater encouragement to optimize the value of the company so that the company performance will also increase. Based on the explanation above, the following hypothesis is made:

H1: Institutional Ownership influences the Company Performance

Managerial ownership is the shares ownership by company management as measured by the percentage of the number of shares owned by management (Sujoko and Soebiantoro, 2007). According to (Anindhita, 2010) managerial stock ownership is the proportion of common shares owned by management. According to (Itturiaga and Sanz, 2000) the managerial ownership structure can be explained from two points of view, that is the agency approach and the asymmetric information process. The agency approach considers the managerial ownership structure as an instrument or tool to decrease agency conflict between claimholder against companies.

The information imbalance approach views the mechanism of managerial ownership structure as a manner to decrease information imbalance between insider and outsider through disclosure of information in the share market. (Gunarsih, 2003) states that company ownership is one form of use of mechanism that can be conducted by managers in accordance with the interests of the company owner. Increasing managerial ownership can be used as a way to deal with agency problems. Managers will be motivated to improve their performance which is also the desire of shareholders, (Lestari and Cahyonowati, 2013) states that the greater the proportion of share ownership in a company, then managements tend to try harder for the interests of shareholders that is not more than them. Managerial share ownership will help the unification of interests between managers and shareholders, so that managers directly get the benefitsfrom the decisions taken and also take responsibility for losses as a consequence of wrong decision making. Based on the explanation above, the hypothesis is made as follows:

H2: Managerial Ownership influences Company Performance

To create good Corporate Governance system in public company in Indonesia, then the accountability of board of commissioner which has been doubted so far must be increased, such as by forming independent commissioners and audit committees (Praditia, 2010). The relationship between the number of commissioners and company values supported by the perspective of service and control functions that can be given by the board. Because these two functions are more likely given by the board of commissioners to the condition of the Corporate Governance structure. The service function states that the commissioner can provide consultation and advice to management and directors (Darwis, 2009). Based on the explanation above, the hypothesis is made as follows:

H3: Audit Committee influences the Company Performance

Independent commissioner is one of the mechanisms of Corporate Governance. The board of commissioners plays a role in conducting the supervisory function, the composition of the board can influence management in preparing financial statements so that a quality earnings report can be obtained (Boediono, 2005). Independent commissioners are a representation of minority interest. The existence of independent commissioners is intended to protect them from possible asymmetry of information and opportunistic management actions. The existence of independent commissioners in Indonesia has been regulated in the Decree of the Directors of the Jakarta Stock Exchange (IDX) Number: Kep 315 / BEJ / 06-2000 regarding Regulation No. IA, concerning Listing of Shares and Equity Securities other than Shares issued by the Listed Company in items regarding Provisions regarding Independent Commissioners. In the regulation stated that in the framework of good corporate governance, companies listed on the JSX must have an independent commissioner proportional to the number of shares owned by non-controlling shareholders 
provided that the number of independent directors is at least $30 \%$ of the total members commissioner. Based on the explanation above, the hypothesis is made as follows:

H4: Independent Commissioner influences the Company Performance

\section{Research Method}

Population in this research is companies in Indonesia Stock Exchange. The sample of this research is company LQ 45 period of 2010-2012. The analysis tool used Multiple Linear Regression Analysis calculated using this formula:

Tobin's $\mathrm{Q}=\alpha+\beta 1 \mathrm{NST}+\beta 2 \mathrm{MGR}+\beta 3 \mathrm{KA}+\beta 4 \mathrm{KI}+\mathrm{e}$

Where:

Tobin's $\mathrm{Q}=$ The measurement of company performance is measured using Tobin's $\mathrm{Q}$ as market performance measure,

$\alpha=$ Constant,

$\beta 1-\beta 4=$ Regression Coefficient,

INST $\quad=$ Percentage of Institutional Share Ownership,

MGR = Percentage of Share Ownership by Managerial,

KA = Audit Committee,

KI = Independent Commissioners,

e $\quad$ error

\section{Analysis and Discussion}

Descriptive statistic analysis aims to find out modus, mean, maximum value, and minimum value. The summary of data is shown in Table 1 .

Table 1. Descriptive Statistics of Variabels $(n=45)$

\begin{tabular}{lcccc}
\hline & Minimum & Maximum & Mean & Std. Deviation \\
\hline Institutional Ownership & 0.18 & 0.85 & 0.64 & 0.17 \\
Managerial Ownership & 0.00 & 0.00 & 0.00 & 0.00 \\
Audit Committee & 0.20 & 1.00 & 0.77 & 0.24 \\
Independent Commissioner & 0.17 & 0.75 & 0.42 & 0.12 \\
Company Performance & 0.30 & 1.91 & 0.84 & 0.40 \\
\hline
\end{tabular}

In Table 1, the average institutional ownership of the company is $64 \%$. Institutional parties have a large influence in influencing all decisions relating to the performance of the company operations. Ownership of shares by a relatively small number of managers cannot influence the decision making by the company in corporate financial reporting. An audit committee that has a financial expertise background can be seen that all companies have committee members of or more than 3 people. This shows that the sample company has met the criteria set by OJK which requires a minimum number of audit committees in a company of 3 people. Based on this number, supervision of the company financial reporting performance is more guaranteed and reduces the risk of fraud. The company independent board of commissioners shows that there are still a number of sample companies that do not meet the BAPEPAM regulations which require that the percentage of the existence of an independent board of commissioners be $30 \%$ on the board. A large number of independent directors is needed in the company as a control of company policy. The Company average performance is considered unattractive. In general, investors prefer companies that have a $\mathrm{Q}$ ratio above one, because it shows that investments in assets generate profits that provide a higher value than investment expenses so that investments become profitable. The results of the multiple linear regression test can be seen in Table 2 as follows: 
Table 2. Result of Multiple Linear Regression Test

\begin{tabular}{lccc}
\hline \multicolumn{1}{c}{ Description } & $\begin{array}{c}\text { Standardized Coefficients } \\
\text { Beta }\end{array}$ & $\mathrm{t}$ & Sig. \\
\hline Constant) & & -1.008 & 0.323 \\
Institutional Ownership & 0.120 & 0.594 & 0.557 \\
Managerial Ownership & -0.016 & -0.089 & 0.930 \\
Audit Committee & 0.352 & 1.619 & 0.118 \\
Independent Commissioner & 0.485 & 2.453 & 0.021 \\
\hline
\end{tabular}

Based on Table 2, obtained multiple linear regression equation as follows:

$\mathrm{Y}=-0.838+0.120 \mathrm{X} 1-0.016 \mathrm{X} 2+0,352 \mathrm{X} 3+0.485 \mathrm{X} 4$

Where:

Y : Company Performance (Tobin's Q), X1: Institutional Ownership,

$\mathrm{X} 2$ : Managerial Ownership,

X3 : Audit Committee,

$\mathrm{X} 4$ : Independent Commissioners

From Table 2 it can be concluded that variable of Institutional Ownership, Audit Committee have significant influence towards Company Performance and Independent Commissioners have not significant influence towards Company Performance (Tobin's Q). Managerial Ownership that has negative influence towards Company Performance (Tobin's Q). Hypothesis test is conducted by testing significance value of from the influence of each independent variable partially to dependent variable.

\section{Discussion}

Institutional ownership cannot have an influence on Company Performance. Ownership of shares by institutions cannot improve Company Performance. The results of this study support the research conducted (Praditia, 2010) which proves that institutional ownership has no influence on firm value. Supervision conducted by institutional shareholders does not affect the company stock price. Managers sometimes take action that escapes the oversight of institutional shareholders. Therefore, in order to improve company performance, managers must feel to be the owner of a company that requires welfare without ignoring company performance. Managerial ownership has no effect on Company Performance. The results showed that managerial ownership dominates the company stock ownership. The results of this study are supported by research conducted (Praditia, 2010) which states that managerial ownership partially has no effect on Company Performance. The greater managerial ownership in a company, the financial information will be quickly known by the owner of the company. As the owner, the manager is also the manager of the company. Meanwhile, other parties can find out the information after the company financial statements are published. the owner's decision is the manager's decision, so the manager can make decisions relating to Company Performance. The large number of audit committees is not a guarantee to increase Company Performance. The audit committee functions to improve the quality and credibility of the financial statements so as not to provide information that can mislead shareholders in making investment decisions. Independent commissioners can have an influence on Company Performance. Independent commissioners are able to improve company performance. The high number of independent directors is not a guarantee that the company performance will get better, so the market considers the existence of independent directors is not a factor taken into consideration in improving company performance. 
There are many factors that cause the absence of managerial ownership, institutional ownership, and audit committee effects on Company Performance. These factors can come from economic factors, both macroeconomic and microeconomic and social factors. Economic factors consist of economic growth, inflation, interest rates, the level of stock prices of products and services produced, government regulations, and the world financial crisis. Social factors consist of social responsibility, trust and lifestyle in society. The rate of economic growth becomes consideration for investors to invest their shares. Investors usually look for countries that have high growth rates. It is hoped that returns are guaranteed. Guaranteed returns will attract investors to invest. It is a guarantee that a company will benefit investors in the future. The impact of inflation is high enough to make the company performance be reduced. Inflation creates instability in terms of economic growth because the increase in inflation is not necessarily followed by an increase in public income. This decrease in inflation occurred because of the interference from Bank Indonesia (BI). BI as the central bank has the authority to determine monetary policy by raising interest rates to reduce inflation. The stock price is an valuation of a company value. Changes that are too volatile in the price of shares can affect the consideration of potential investors in investing their shares in company. Prospective investors are not willing to take risks against companies whose price levels are fluctuating. This led to protests from the surrounding community because they were short of water for their daily activities as farmers. Prospective investors also see this as their consideration in investing in a company.

\section{Conclusions}

Institutional ownership and Managerial Ownership do not have significant affect towards Company Performance. Managerial ownership is dominated by the large number of shareholders of the company. Audit committees do not have affect towards Company Performance. The independent board of commissioners influences the Company performance. This indicates that the proportion of independent board of commissioners cannot make changes to the Company performance.

\section{Suggesstion}

For management, management gives attention to other components of Corporate Governance such as intensive management systems, the quality of auditors and company secretaries and external factors such as inflation rates, government regulations. This research should be used as a comparison and consideration for future research. Using company samples that are not only in LQ45 company, but can be developed using samples from other groups of companies listed on the Indonesia Stock Exchange. Extend observation year periods by different periods of time. Using other variables such as inflation, ROE, ROA, CSR.

\section{References}

Anindhita. (2010). Pengaruh corporate governance dan struktur kepemilikan terhadap kinerja perusahaan, Skripsi. Semarang: Undip 2010.

Arafat, W. (2006). Behind A Powerful Image: Menggenggam Strategi dan Kunci-kunci Sukses Menancapkan Image Perusahaan yang Kokoh. Yogyakarta: Andi Press.

Bathala, C. T. K. P., Moon., \& R. T. Rao. (1994). Manageral onership, debt policy, and the impact of institutional holdings: an agency perspective. Financial management, 23, 38-50.

Beasley, M. (1996). An Empirical Analysis of the Relation between the Board of Director Composition and FinancialStatement Fraud. American Accounting Association.The Accounting Review, 71(3), 443-465. 
Boediono, G. S. B. (2005). Kualitas Laba: Studi Pengaruh Mekanisme Corporate Governancedan Dampak Manajemen Laba dengan Menggunakan Analisis Jalur". Simposium Nasional Akuntansi VIII, Bali.

Cornelius. (2007). Good Corporate Governance dan penerapannya di Indonesia. Jurnal Manajemen dan Kewirausahaan, 8(1), 1-9.

Darwis, H. (2009). Corporate Governance Terhadap Kinerja Perusahaan, Jurnal Keuangan dan Perbankan, 13(13), 418-430.

Eisenhardt, K. M. (1999). Agency Theory: An Assesment and Review. Academy of management Review, 14, 57-74.

Faisal. (2005). Analisis Agency Cost, Struktur Kepemilikan dan Mekanisme Corporate Governance. Jurnal Riset Akuntansi Indonesia, 8(2).

Febriyani, A., \& Zulfadin, R. (2003). Analisis Kinerja Bank Devisa dan Bank Non Devisa di Indonesia. Jurnal Ekonomi dan Keuangan, 4, 195-201.

Gunarsih, T. (2003). Pengaruh Struktur Kepemilikan dalam Corporate Governance dan Strategi Diversifikasi Terhadap Kinerja Perusahaan. Thesis. Universitas Gajah Mada.

Wibisono, H. (2004). Pengaruh Earnings Management Terhadap Kinerja Di Seputar SEO. Tesis . Magister Sains Akuntansi Universitas Diponegoro.

Hasibuan, M. S. P. (2012). Manajemen Sumber Daya Manusia. Jakarta: PT. Bumi Aksara.

Itturiaga, F. J. L., \& Sanz. J.A.R. (2000). Ownership Structure, Corporate Value and Firm Investment: A Spanish Firms Simultaneous Equation Analisis. Working paper Universidad, de Valladolid, 1-23

Kartikawati, W. (2007). Pengaruh Kepemilikan Institusional Terhadap Kinerja Keuangan Perusahaan. Skripsi. (http://hana3.wordpress.com/2009/05/17/ pengaruh kepemilikan institusional-terhadap-kinerja-keuangan perusahaan/) diakses tanggal 8 Maret 2013).

Keputusan Menteri Badan Usaha Milik Negara Nomor KEP117/M-MBU 2002.

Lestari, P. P., \& Cahyonowati. N. (2013). Pengaruh Good Corporate Governance Terhadap Kinerja Perusahaan. Diponegoro Journal of Accounting, 2(4), 1-13.

Makhdalena. (2009). Pengaruh Komisaris Independen Terhadap Internal Control. Pekbis Jurnal, $1(1), 58-65$.

Praditia, O. R. (2010). Analisis Pengaruh Mekanisme Corporate Governance terhadap Manajemen Laba dan Nilai Perusahaan Pada Perusahaan Manufaktur Yang Terdaftar Di Bursa Efek Indonesia (BEI) Pada Tahun 2005-2008. Skripsi: Fakultas Ekonomi, Universitas Diponegoro.

Shieifer, A., \& R.W. Vishny. (1997). A Survey of Corporate Governance. Journal of Finance, 52(2), 737-783.

Shien. (2006). Financial Accounting Theory 3th editon. Pearson Prentice Hall.

Sujoko., \& Soebiantoro. (2007). Pengaruh Struktur Kepemilikan Saham, Leverage, Faktor Intern, dan Faktor Ekstern Terhadap Nilai Perusahaan. Jurnal Manajemen dan Kewirausahaan, 9(1), 41-48. 
Sulistiyani, A. T., \& Rosidah. (2003). Manajemen Sumber Daya Manusia. Graha Ilmu: Yogyakarta.

Pranata, Y. (2007). Pengaruh Penerapan Corporate Governance Terhadap Kinerja Keuangan Perusahaan.Skripsi. Universitas Islam Indonesia. Yogyakarta. 